\title{
一方向高密度航空交通流におけるパイロットの操縦による自律間隔維持*1 A Self-Separation Algorithm in a High Density Air Corridor Feasible for a Human Pilot Control
}

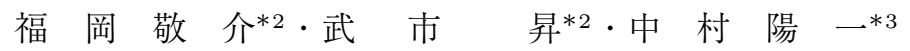 \\ Keisuke Fukuoka, Noboru TAKeIchi and Yoichi Nakamura
}

Key Words : Air Traffic Management, Air Corridor, Self-Separation, Human Pilot Control

\begin{abstract}
A high density air corridor is expected to be an air space where aircraft capable of airborne self-separation are allowed to fly into the same direction. A self-separation algorithm in a high density air corridor that is feasible for the human pilot manual control is discussed in this study. In addition, the corridor width limitation is also considered to definitely prevent any conflict against the aircraft outside the corridor. Through a series of the traffic simulation, it has been clarified that an algorithm that indicates the fixed heading change to the pilot is able to achieve a safe corridor operation in combination with flight speed control. It is also clarified that the information of the intended flight speed and the collaborative separation control are indispensable for the air corridor efficient operation.
\end{abstract}

\section{1. 緒言}

洋上経路や特定の混雑空港間の飛行経路では多くの航空 機が同一の方向へ飛行している。現在は管制官がこれらの 航空機の位置を把握して指示をする集中型の管制が行われ ているが，管制官が各航空機の位置情報を得てから管制指 示を送るまでの通信および判断の一連の手順に一定の時間 を要するため, 各航空機は大きな管制間隔を維持して航行 しなければならない，例えば太平洋の洋上経路（第 1 図） においては, 衛星通信を用いた航空管制が行われているが, 進行方向の管制間隔は $30 \mathrm{NM}^{* 4}$ となっている ${ }^{1,2)}$. 洋上経 路は第 2 図に示すような多数の経路の候補から気象状況に 応じた最適なものが選択されるが3), 利便性のよい時間帯 に多くの航空機が集中するため, 必ずしもすべての航空機 が最適な経路上を飛行できるとは限らない状況にある。一 方で航空輸送の需要は年々増加し続けており4), 管制間隔 短縮による交通容量拡大が必要である5).

一方, 近年 ASAS (Aircraft Surveillance Applications System) と呼ばれる航空機間隔維持支援装置の開発が 進んでいる6)。これは ADS-B (Automatic Dependent Surveillance-Broadcast) と呼ばれる空対空監視用の通信 媒体を使用し, 各航空機が互いの位置情報等を送受信する ことにより, 機上で周辺の交通状況を把握することを可能

*1 C 2014 日本航空宇宙学会

平成 25 年 11 月 21 日, 第 51 回飛行機シンポジウムにおいて発 表. 平成 25 年 9 月 3 日原稿受付

*2 名古屋大学大学院工学研究科航空宇宙工学専攻

*3 電子航法研究所航空交通管理領域

${ }^{* 4} \mathrm{NM}=1852 \mathrm{~m}$ である. 航空交通管理の分野では水平方向の距離の 単位として一般に NM が用いられるため, 本稿においても同様 にNM を用いる.
とするシステムである。この機能を用いることにより各航 空機のパイロットは管制官の指示を必要とすることなく独 自に間隔維持をすることが可能となり, これにより分散型 の制御が可能となるものと考えられている7 9). これにより 管制間隔を短縮することができ，より多くの航空機が最適 経路上を飛行することが可能となると考えられている。ま た同時に管制官のワークロードの低減も実現できるため, より安全で効率のよい交通流を実現することが期待されて いる.

航空交通の分散制御に関しては，これまでに衝突回避 10 13) や降下中の間隔維持14 17) への応用が多く研究されてきた. また筆者らはこれまでに洋上経路や特定の混雑空港間など, 一方向の航空交通流を安全かつ効率的に運用するための間 隔維持方法を明らかにし18 20), さらに各航空機の間隔維持 の振る舞いにばらつきがあると安全性が損なわれることを 明らかにしている21)。また，そのような安全性が損なわれ ると予想される状況で各航空機は周辺の交通状況を監視し, その情報をもとに飛行速度を調整することでコンフリクト と呼ばれる他の航空機との危険な接近を回避できることを 明らかにした22)。しかし, これまでの研究では, 各航空機 の機上装置が近傍の他の航空機の情報に基づいて自動的に コンフリクトの可能性を判断し，コンフリクトの可能性が ある場合にはそれを回避するように航空機を自動的に誘導 し, 機上装置がその誘導に従って自動的に航空機を操作す ることを前提としていた。しかし実際の航空交通において は監視, 誘導, 制御の一連の操作をすべて自動で行う機種 および部分的にパイロットが行う機種が混在することが想 定される.そのような状況ではパイロットの手動の操作で も間隔を維持できるアルゴリズムが望ましい. 本研究では 監視, 誘導, 制御のうち, まず制御をパイロットの手動の 


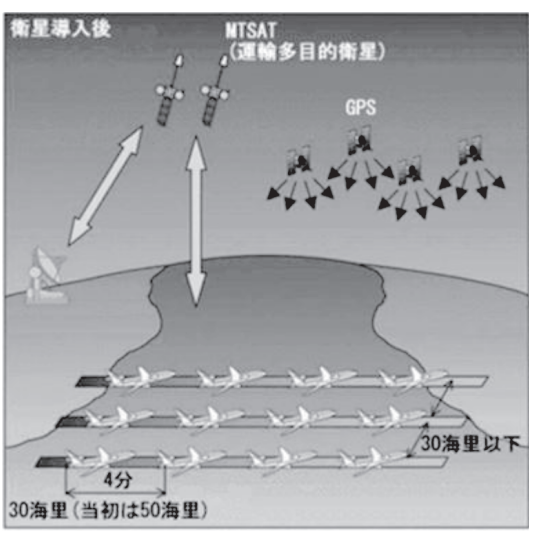

第 1 図 現在の洋上航空交通管制 22

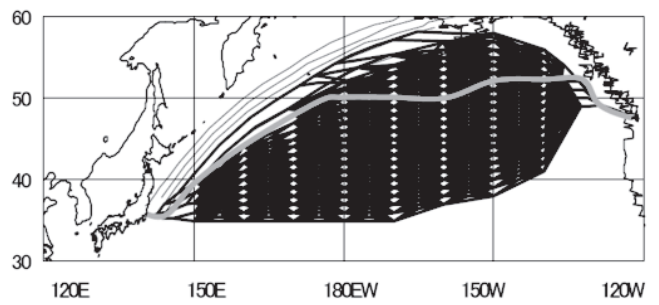

第 2 図 現在の洋上経路の構成 ${ }^{3)}$

操作で行うことを想定し，一方向高密度航空交通流の安全 な運行を可能とする自律間隔維持方式を明らかにする。ま た将来の航空交通システムでは，フローコリドーと呼ばれ る細長い空域を導入しその中に自律間隔維持の機能を持つ 航空機からなる高密度の交通流を実現し, 空域全体として 安全性を損なうことなく効率を向上させることが計画され ている7,8,23).このとき, フローコリドー内の航空機は安全 のため外部空域へ逸脱することは許されない。そこで本研 究では, 新たに空域の横幅の厳密な制限を考慮する.

\section{2. 航空交通流の力学モデル}

2.1 航空機の力学モデル 本研究では第 3 図のように 進行方向を $x$ 軸, 進行方向に対し右側を $y$ 軸, 垂直下向 きに $z$ 軸を定める。 また, 速度を $V[\mathrm{~m} / \mathrm{s}]$, 重力加速度を $g\left[\mathrm{~m} / \mathrm{s}^{2}\right]$, 推力を $f_{T}\left[\mathrm{~kg} \cdot \mathrm{m} / \mathrm{s}^{2}\right]$, 機体質量を $m[\mathrm{~kg}]$, 揚力 係数を $C_{L}$, ロール角を $\phi[\mathrm{rad}]$, 方位角を $\psi[\mathrm{rad}]$, 経路角 を $\gamma[\mathrm{rad}]$, 密度を $\rho\left[\mathrm{kg} / \mathrm{m}^{3}\right]$, 翼表面積を $S\left[\mathrm{~m}^{2}\right]$, 有害抵 抗係数を $C_{D 0}$, 誘導抵抗係数を $C_{D 2}$ とする. 質量, 翼面 積, 有害抵抗係数, 誘導抵抗係数は Boeing777 の值である, $m=200 \times 10^{3}[\mathrm{~kg}], \quad S=427\left[\mathrm{~m}^{2}\right], \quad C_{D 0}=1.69 \times 10^{-2}$, $C_{D 2}=4.89 \times 10^{-2}$ を用いる ${ }^{24)}$. このとき, 航空機の運 動方程式は以下の通りに得られる。

$$
\begin{aligned}
& \dot{x}=V \cos \gamma \cos \psi \\
& \dot{y}=V \cos \gamma \sin \psi \\
& \dot{z}=-V \sin \gamma \\
& m \dot{V}=f_{T}-\frac{1}{2} \rho S V^{2}\left(C_{D 0}+C_{D 2} C_{L}{ }^{2}\right)-m g \sin \gamma
\end{aligned}
$$

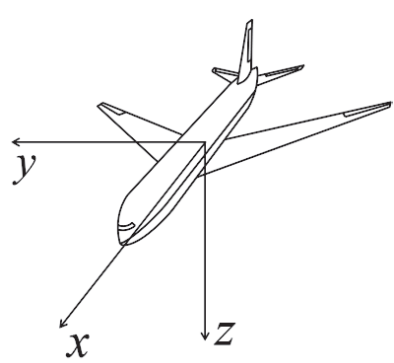

第 3 困 航空機の座標系

$$
\begin{aligned}
m V \dot{\gamma} & =\frac{1}{2} \rho S V^{2} C_{L} \cos \phi-m g \sin \gamma \\
m V \dot{\psi} & =\frac{1}{2} \rho V^{2} S C_{L} \frac{\sin \phi}{\cos \gamma}
\end{aligned}
$$

ただし，本研究では風の影響は考慮せず，機上では航空機 の正確な対地速度を得られるものとする。各航空機は運動 方程式中のロール角 $\phi$, 揚力倸数 $C_{L}$ を制御入力として与 え横方向と縦方向の運動を行う ${ }^{22}$. また本研究では各航空 機にはそれぞれ最適な飛行速度が存在するものとし, 対象 とする交通流内には最適速度が $230[\mathrm{~m} / \mathrm{s}]$ から $250[\mathrm{~m} / \mathrm{s}]$ の 航空機が混在するものとする. 航空機 $i$ の最適速度を $V_{o i}$ とし, 間隔維持を行わない場合はその最適速度で飛行する ものとする. 各航空機には以下のような式で揚力倸数を与 え高度を維持する. 式中の $h_{i}$ は航空機 $i$ の飛行高度を表す.

$$
\begin{aligned}
& C_{L i}=C_{L 0 i}+\Delta C_{L i} \\
& C_{L 0 i}=\frac{2 m g}{\rho S V_{o i}{ }^{2}} \\
& \Delta C_{L i}=\alpha_{1}\left(h_{i}+z_{i}\right)
\end{aligned}
$$

(8) 式の $C_{L 0 i}$ は航空機が定常状態において $\dot{\gamma}=0$ となるよ うに (5) 式より得られる值であり, $\Delta C_{L i}$ は飛行高度を維持 するように与えられる. また航空機 $i$ の推力定常值 $f_{T i}$ は 定常時に最適速度 $V_{o i}$ で航行するように一定で与える $f_{t o i}$ と目標の速度に加減速するための項である $k a_{i}$ の和で与え られる。 $f_{t i}$ は (10) 式で, $f_{t o i}$ は式 (4) より (11) 式となる.

$$
\begin{aligned}
& f_{T i}=f_{T o i}+k a_{i} \\
& f_{T o i}=\frac{1}{2} \rho S V_{o i}{ }^{2}\left(C_{D 0}+C_{D 2} C_{L 0 i}{ }^{2}\right)
\end{aligned}
$$

(11) 式の $a$ は航空機の目標速度への加減速を表し, 目標速 度 $V_{g}$ と現在の速度を使用し次のように表される。

$$
a_{i}=V_{g i}-V_{i}
$$

本研究では, 安全を保つために各航空機が維持する必要が ある間隔として安全間隔 $d_{s}$ を定め, 航空機の間隔がこの安 全間隔を下回った状態を衝突の可能性がある危険な状態と 解釈する。そしてこのような安全間隔以下までの接近状態 をコンフリクトと定義する，また安全間隔より少し大きい 值として基準間隔 $d_{c}$ を定める. 各航空機はこの間隔を基準 に旋回や飛行速度の加減速により他の航空機と間隔維持を 


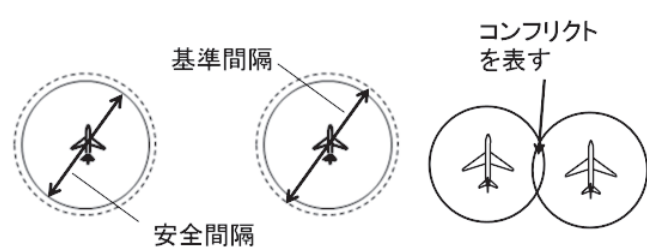

第 4 図＼cjkstart航空機の安全間隔および基準間隔

行い所要の間隔を維持する。第 4 図に安全間隔，基準間隔， およびコンフリクトを示す，航空機の周りに実線で書かれ た円の直径が安全間隔，破線で書かれた円の直径が基準間 隔を表す，2つの航空機の実線で書かれた円が重なったと きにはコンフリクトが発生していることを示す. 本研究で はパイロットが操作可能な間隔維持手順にするために, 旋 回により間隔維持をする際, 各機は常に進行方向に対して 左右いずれかに $5[\mathrm{deg}]$ だけ旋回するものとする．旋回角を 一定值に定めることで複雑かつ精密な旋回角の操作を必要 とせず，周辺の交通情報をもとに計算される間隔維持の誘 導にパイロットの手動の操作でも追従することができるも のと考えられる. また本研究では 20 機の航空機の運動解 析を行うものとする。経路の縦方向は 20 機の航空機が基 準間隔で列をなした場合と等しい長さ $(10.5 \mathrm{NM} \times 20=$ $210 \mathrm{NM}$ ) を解析対象とし, 経路の先端扔よび後端が連続し ているものとして無限遠の経路を模擬する。また横幅につ いては, 最適経路から $\pm 2.5 d_{c}( \pm 26.25 \mathrm{NM})$ の位置まで を航空機が移動可能な範囲として定める. 各航空機はこの 解析経路内を周辺の航空機と間隔維持を行い航行する.

\section{2 自律間隔維持モデル}

2.2.1 監視モデル 各航空機は第 5 図に示す範囲内の航 空機を監視する。本研究では第 5 図の監視範囲の長方形の 横幅を $2 d_{c}$, 縦幅を $4 d_{c}$ とした。 その監視範囲内に他の航 空機が存在し, かつ前方に自機以下の速度で飛行する航空 機が存在する場合，もしくは後方に自機以上の速度で飛行 する航空機が存在する場合に，今後基準間隔以下に接近す る可能性が高いと判断する。，その場合に各機は以下に説明 する手順で間隔維持を行い安全間隔を維持する. 本研究で はこのとき監視した航空機を間隔維持対象機と呼ぶ。また 前方と後方に基準間隔以下に接近する可能性がある航空機 が複数存在する場合, 自機と水平方向の間隔が最も小さい 航空機を間隔維持対象機として間隔維持を行う。監視範囲 内の最も接近している航空機を間隔維持対象機とすること で，その瞬間に安全間隔以下に最も接近する可能性が高い 航空機と間隔維持をすることができる。

2.2 .2 旋回方向の決定 各航空機は旋回により間隔維持 対象機と安全間隔を維持することを試みる。本研究では自 機と間隔維持対象機の最適速度を比へ速度が速い場合右へ, 遅い場合左へ旋回する。このときの旋回方向を旋回順方向 と定める. 航空機が密集し旋回順方向に旋回できない場合 は逆方向に旋回し間隔を維持する。この向きを旋回逆方向 と定める, 最適速度の差により旋回方向を定めることで, 速 度差の大きな航空機間の間隔維持の必要性を低減し, 安全

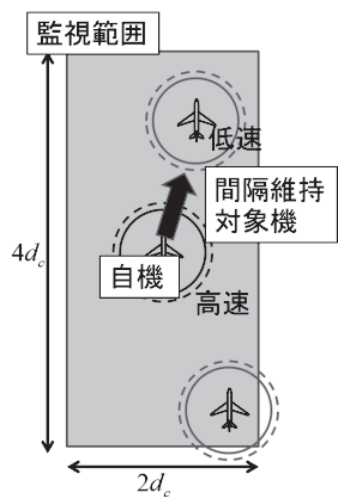

第 5 図 間隔維持対象機

性を損なうことなく各航空機のワークロードを均等に大幅 に低減することが期待できる25).

2.2.3 間隔維持アルゴリズム 各航空機は上記の旋回方 向をもとに以下で示す(1)から (6)の目標経路へ経路変更し間 隔を維持する. (1)から (6)では航空機 $i$ を自機, 航空機 $j$ を間 隔維持対象機として扱う。経路を变更する場合に周辺航空 機とのコンフリクトの発生可能性を(1)から順に評価し, 安 全に旋回できる場合はその目標経路へ旋回し間隔維持を行 う. $V_{i}>V_{j}, y_{i}>y_{j}$ の場合のアルゴリズムに基づいた目 標経路を第 6 図 (a)〜 (f) に示す.

(1) 航空機 $i ， j$ が共に旋回順方向に安全に旋回できる場 合，それぞれ旋回順方向の

$$
\frac{\left(y_{i}+y_{j}\right)}{2} \pm \frac{1}{2} d_{c} \cdot \operatorname{dire}\left(V_{o i}-V_{o j}\right)
$$

に進路変更を行う（第 6 図 (a)）.

(2) 航空機 $i$ は旋回順方向に安全に旋回でき, 他の航空機 が存在する等の理由で航空機 $j$ が旋回順方向に安全に旋回 できない場合，自機 $i か ゙$ 旋回順方向の

$$
y_{j}+d_{c} \cdot \operatorname{dire}\left(V_{o i}-V_{o j}\right)
$$

へ経路変更し, 航空機 $j$ は直進する（第 6 図 (b)).

(3) 他の航空機が存在する等の理由で航空機 $i$ が旋回順方 向に旋回できず，航空機 $j$ が旋回順方向に安全に旋回でき る場合, 航空機 $j$ が旋回順方向の

$$
y_{i}-d_{c} \cdot \operatorname{dire}\left(V_{o i}-V_{o j}\right)
$$

一経路変更し，航空機 $i$ は直進する（第 6 図 (c)).

(4) 航空機 $i, j$ 共に旋回逆方向に安全に旋回できる場合, 航空機 $i, j$ がそれぞれ旋回逆方向の

$$
\frac{\left(y_{i}+y_{j}\right)}{2} \mp \frac{1}{2} d_{c} \cdot \operatorname{dire}\left(V_{o i}-V_{o j}\right)
$$

に経路変更を行う（第 6 図 (d)).

(5) 航空機 $i$ が旋回逆方向に安全に旋回でき, 他の航空機 が存在する等の理由で航空機 $j$ が旋回逆方向に旋回できな い場合, 自機 $i$ が旋回逆方向の

$$
y_{j}-d_{c} \cdot \operatorname{dire}\left(V_{o i}-V_{o j}\right)
$$


(a)
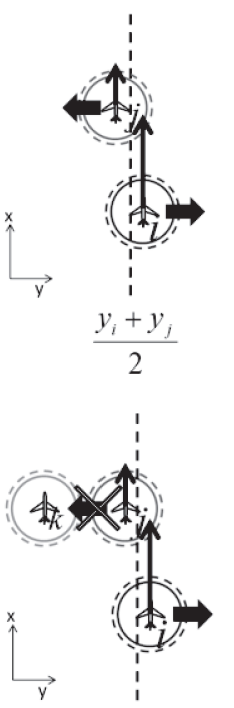

(b)
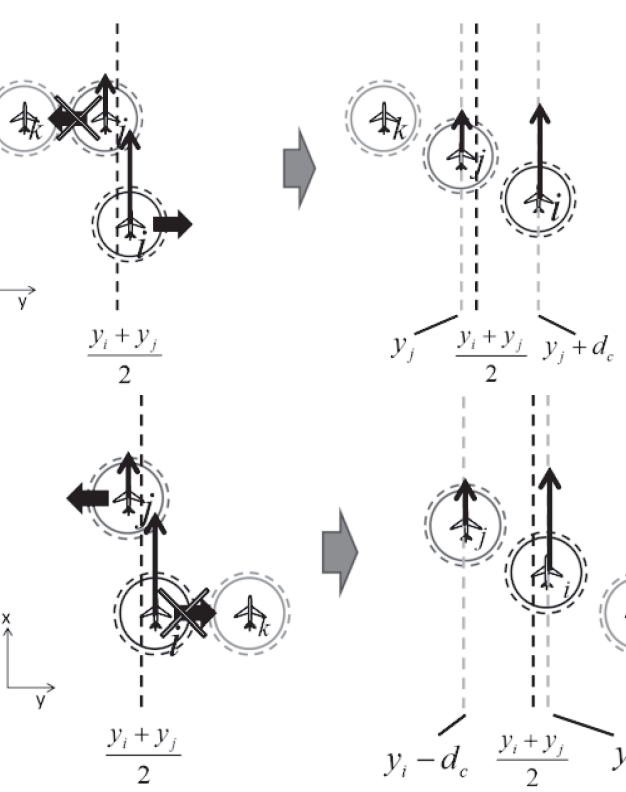

(c)
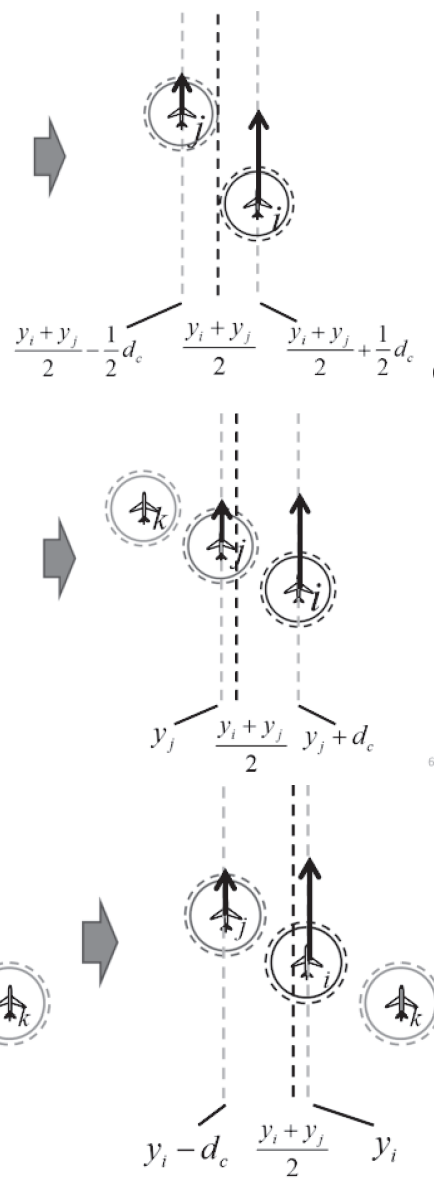

(f)

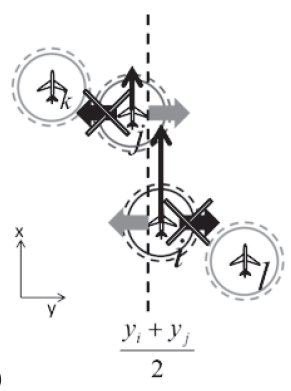

(d)
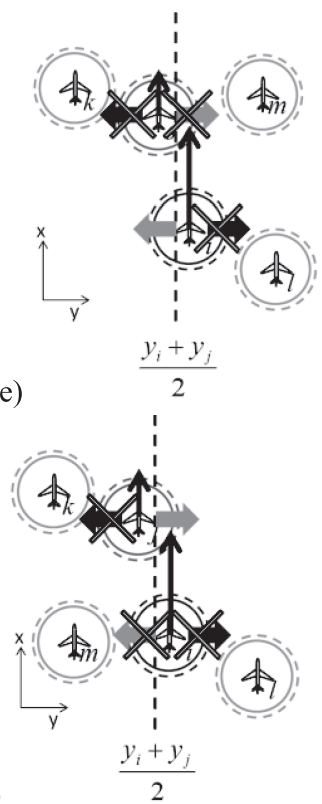

(e)

第 6 図 間隔維持の目標経路

へ経路変更し, 航空機 $j$ は直進する（第 6 図 (e)).

(6) 他の航空機が存在する等の理由で航空機 $i$ が旋回逆方 向に旋回できず，航空機 $j$ が旋回逆方向に安全に旋回でき る場合, 航空機 $j$ が旋回逆方向の

$$
y_{i}+d_{c} \cdot \operatorname{dire}\left(V_{o i}-V_{o j}\right)
$$

へ経路変更し, 航空機 $i$ は直進する（第 6 図 (f)).

ここで $\operatorname{dire}(x)$ は以下の式で与えられ, $x \geq 0$ のとき +1 , $x<0$ のとき -1 となるような関数である.

$$
\operatorname{dire}(x)= \begin{cases}1 & : x \geq 0 \\ -1 & : x<0\end{cases}
$$

また，コンフリクトを発生せずに安全に経路変更できるか という判断は以下の考え方に基づいて行う. 旋回を開始す る航空機を $i$, 周辺を航行するある航空機を $j$ とする。評 価開始時間を時刻 $t=0$ として，そのときの航空機 $i, j$ の 位置を $\left(x_{0 i}, y_{0 i}\right),\left(x_{0 j}, y_{0 j}\right)$ とする. 航空機 $i, j$ の速度 $V_{i}, V_{j}$ 方位角 $\psi_{i}, \psi_{j}$ を用いるとある時刻 $t$ での航空機 $i$, $j$ の位置は次の式で予測できる.

$$
\begin{aligned}
& \vec{r}_{i}=\left(x_{0 i}+V_{i} \cos \psi_{i} \cdot t, y_{0 i}+V_{i} \sin \psi_{i} \cdot t\right) \\
& \vec{r}_{j}=\left(x_{0 i}+V_{j} \cos \psi_{j} \cdot t, y_{0 j}+V_{j} \sin \psi_{j} \cdot t\right)
\end{aligned}
$$

この 2 式を用いると時刻 $t$ での航空機 $i, j$ の間隔の 2 乗は
次のように予測できる。

$$
\begin{aligned}
& d_{i, j}^{2}=a t^{2}+b t+c \\
& b=2\left(x_{0 i}-x_{0 j}\right)\left(V_{i} \cos \psi_{i}-V_{j} \cos \psi_{j}\right) \\
& -2\left(y_{0 i}-y_{0 j}\right)\left(V_{i} \sin \psi_{i}-V_{j} \sin \psi_{j}\right) \\
& c=\left(x_{0 i}-x_{0 j}\right)^{2}+\left(y_{0 i}-y_{0 j}\right)^{2}
\end{aligned}
$$$$
a=\left(V_{i} \cos \psi_{i}-V_{j} \cos \psi_{j}\right)^{2}+\left(V_{i} \sin \psi_{i}-V_{j} \sin \psi_{j}\right)^{2}
$$

また航空機 $i$ の目標経路を line $(i)$ とすると旋回により経路 を変更するまでに要する時間 $t_{f}$ は次のようになる。

$$
t_{f}=\frac{\left|\operatorname{line}(i)-y_{0 i}\right|}{V \sin \psi_{i}}
$$

(20) 式より $0 \leq t \leq t_{f}$ の範囲で最小值を求め, 予測され る航空機 $i, j$ の最小間隔 $d_{i, j \text { min }}$ を求めると航空機 $i$ が航 空機 $j$ と基準間隔以下に接近することなく安全に旋回でき る条件は次のようになる。

$$
d_{i, j \min }>d_{c}
$$

このように航空機 $i$ の周辺を航行する航空機すべてに対し, 目標経路へ移動する際の最小間隔を計算し，(21) 式をすべ ての航空機で満たした場合のみ安全に旋回できると判断す 
(a)
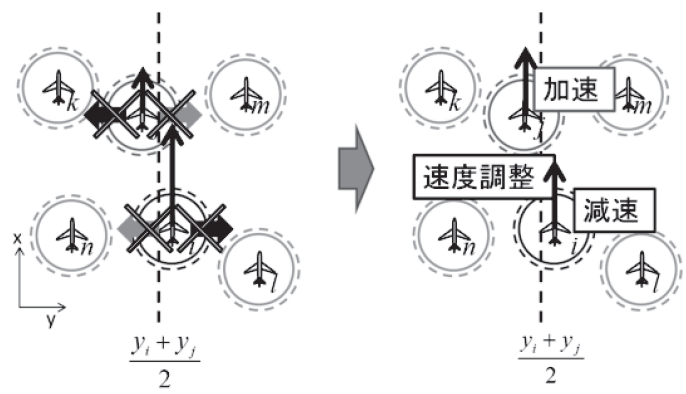

(b)
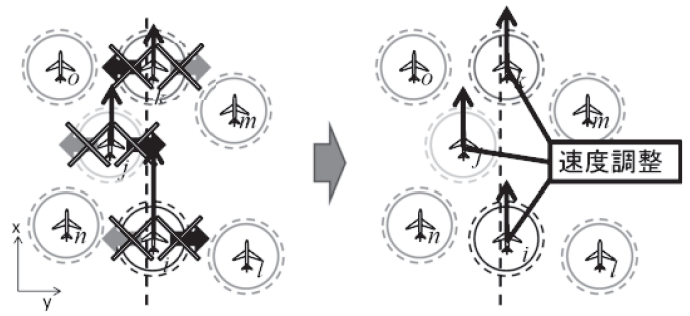

第 7 図 速度調整

(a) 2 機の場合, (b) 3 機以上の場合

る。また間隔維持のために(1)から (6)で与えられる目標経路 が 2.1 章で定めた解析経路の横幅の外側に存在する場合, 周 辺の航空機の状況にかかわらず，その経路に旋回できない と判断する。(1)から6のいずれの目標経路へも安全に経路 変更できないと判断した場合は航空機 $i$ と航空機 $j$ は速度 調整を行う。そのときの状況を第 7 図 (a) に示す。このと きこれら 2 機はその最適速度の平均の速度で飛行する。速 度調整中(1)から(6)のいずれかの経路に経路変更できると判 断できた場合, その経路へ移動した後, 速度調整を解除し 自機の最適速度で飛行する。 また第 7 図 (b)のように 3 機 以上で速度調整が必要な場合, 速度調整が必要な航空機は, それらすべての航空機の最適速度の平均值で飛行する。

\section{3. 航空交通流シミュレーション}

前章の運動方程式および間隔維持方法を用いて同一の交 通流内を飛行する 20 機の航空機の 20 時間の運動解析を 50 通りの初期值に対して行い, 交通流の振る舞いを調べた。数 值解析で用いたパラメー夕を第 1 表に示す。初期状態では, すべての航空機が解析範囲である縦 $210 \mathrm{NM}$, 横 $52.5 \mathrm{NM}$ の長方形内に配置する。縦方向は基準間隔ごとに等間隔に, 横方向は不規則に配置されている。第 8 図に初期状態およ びその後の 24000 秒ごとの振る舞いの一例を示す。第 8 図 の各交通流の真中の破線が最適経路を示し, 最適経路の両 端の破線までを航空機が移動可能であることを示す。また 第 8 図の航空機の周りが黒塗りになっている航空機は他の 航空機と速度調整を行っていることを表す。また航空機に 書かれた矢印の長さが各航空機の飛行速度の目安を示す。 前章より各航空機は間隔維持対象機との最適速度差に応じ て, 速い場合は右に, 遅い場合は左に旋回することを優先 して間隔維持をするため, 右に行くほど高速な航空機が飛 行する交通流が時間経過に伴い形成される，第 2 表に間隔 維持を旋回のみで行う場合と旋回と速度調整を行う場合の
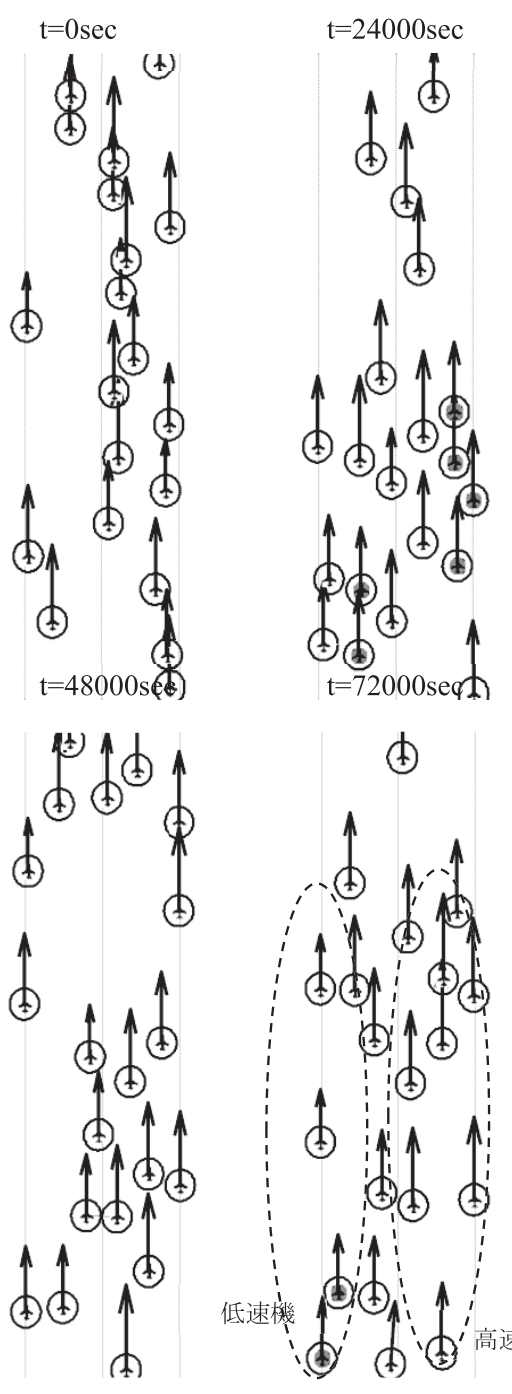

()

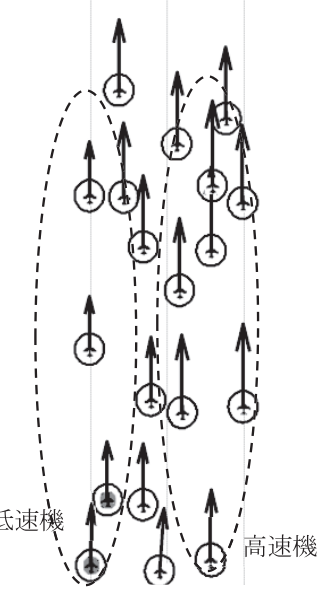

第 8 図 交通流の振る舞い

第 1 表 交通流パラメー夕

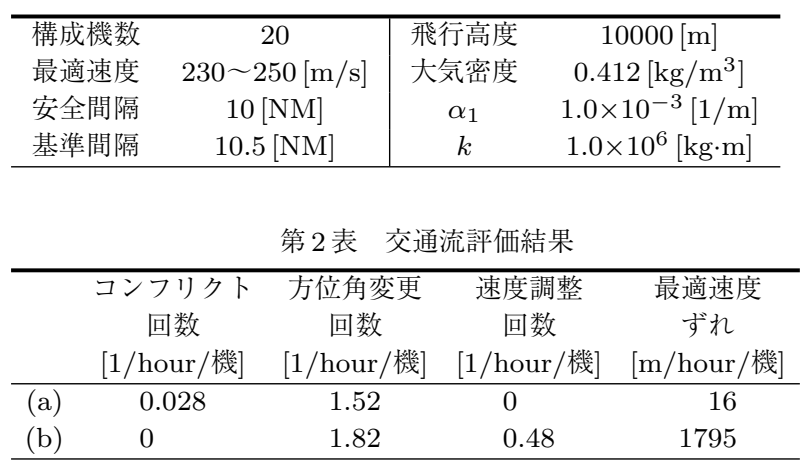

数值解析の結果を示す. (a) が速度調整を行わない評価結 果, (b) が速度調整を行う評価結果を示す. 第 2 表のコン フリクト回数, 方位角变更回数, 速度調整回数, 最適速度 ずれは 1 機当たり 1 時間当たりの平均の值を示す。ここで 方位角変更回数, 速度調整回数とはパイロットが間隔維持 のために方位角および速度を変更した回数をそれぞれ表し, パイロットのワークロードを表す指標となる。本研究では この 2 つの值の合計值をパイロットの操作回数とする。ま 
た最適速度ずれは以下の式で表される。

$$
E_{V}=\sum_{i} \int\left|V_{0 i}-V_{i}\right| \mathrm{d} t
$$

最適速度ずれは自分の最適速度 $V_{0}$ から現在の飛行速度 $V$ を引いた值の絶対值の時間積分となっている。つまりこの 值が大きいほど燃料の浪費やスケジュールからの遅れが大 きいことを表す．第 2 表の (b) より速度調整を行った結果, 安全性を評価する指標であるコンフリクト回数の值が 0 で あり, 前章の間隔維持方法で航空機が航行する場合安全な 交通流を形成することができることが明らかとなった。 ま たパイロットのワークロードを示す方位角変更回数と速度 調整回数の值の合計より, 各航空機のパイロットは 1 時間 当たり平均 3 回未満の操作で間隔を維持していることが明 らかとなった。この結果より, 分散型制御を行う際, 専用 の自動操縦装置が無くても人間のマニュアルの操縦で独自 に間隔維持できるようになるものと考えられる。しかし第 2 表より，旋回だけでは間隔維持をすることができず，速 度調整も行う必要があるため最適速度からのずれに伴う燃 料消費量の増加やスケジュールからの遅れを評価すること が今後の課題である。

\section{4. 自律間隔維持に用いる情報}

4.1 使用する情報による振る舞いの変化 1 章で述べた ように本研究では各航空機が周辺の航空機の情報を得る手 段としてADS-B と呼ばれる現在の位置, 高度, 速度を自 動で送受信するシステムの使用を想定している．2 章の間 隔維持方法では上で述べた ADS-B の情報の他に周辺航空 機の最適速度や目標経路, 間隔維持方法の情報を使用して いる. 本章では周辺航空機の最適速度, 間隔維持方法の情 報の重要性を明らかにするため, これらを使用しない間隔 維持方法の数值解析を行い，どのような影響が生じるかを 検証する。

4.2 周辺航空機の最適速度情報を使用しない場合 3 章 の間隔維持アルゴリズムでは効率の良い旋回方向を決定す るために周辺航空機の現在の速度の他に最適速度の情報を 用いた。本章では間隔維持に周辺機の最適速度を使用しな い制御方法で数值解析を行う. 自分と相手の現在の飛行速 度を比へ，旋回順方向を自機の速度が速い場合は右，遅い 場合は左と定め, 2.2 .3 章と同じ間隔維持アルゴリズムを用 いて交通流の解析を行った。また速度調整を行う際は, 自 機と間隔維持対象機の速度調整を行う直前の飛行速度を用 いて，拉互いがその平均值で飛行するように速度調整を行 う. 第 9 図と第 3 表の (c) に交通流の振る舞いの一例と解析 結果を評価したものを示す。第 9 図より, 最適速度を使用 する場合に比べ，高速な航空機ほど右側を飛行するといっ た飛行速度に応じた交通流が形成されず，速度差のある航 空機と間隔維持を行っている。.また第 3 表より, 最適速度 ずれの值が (b) に比べ大きいことが読及取れる。速度に応 じた経路を飛行する場合に比べ間隔維持回数が増加したこ とに伴い, 速度調整の回数, 速度調整時間も増加しこのよ
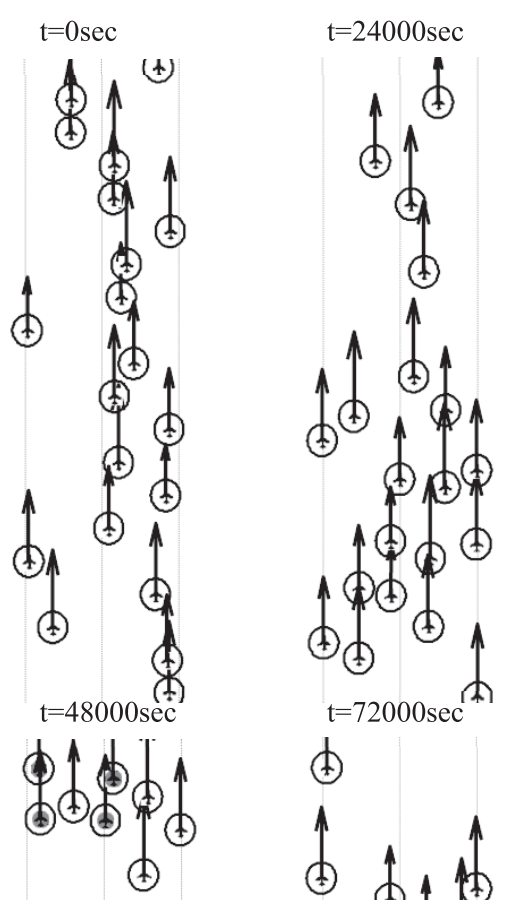

b)
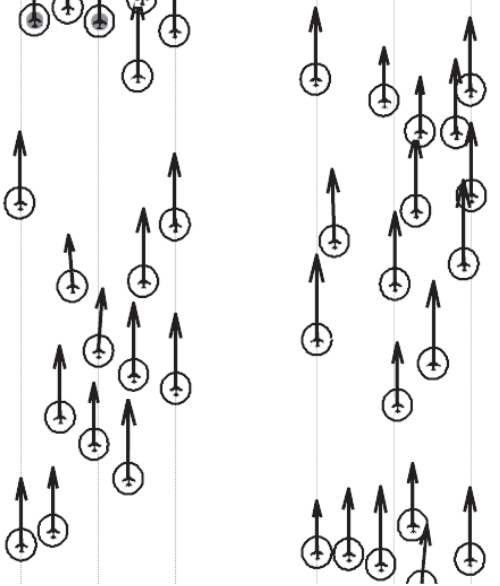

第 9 図 交通流の振る舞い（最適速度情報を使用しない場合）

第 3 表 交通流評価結果（最適速度の情報を使用しない場合）

\begin{tabular}{ccccc}
\hline $\begin{array}{c}\text { コンフリクト } \\
\text { 回数 } \\
{[1 / \mathrm{hour} / \text { 機 }]}\end{array}$ & $\begin{array}{c}\text { 方位角変更 } \\
\text { 回数 } \\
{[1 / \mathrm{hour} / \text { 機 }]}\end{array}$ & $\begin{array}{c}\text { 速度調整 } \\
\text { 回数 } \\
{[1 / \mathrm{hour} / \text { 機 }]}\end{array}$ & $\begin{array}{c}\text { 最適速度 } \\
\text { ずれ } \\
{[\mathrm{m} / \mathrm{hour} / \text { 機 }]}\end{array}$ \\
\hline (c) & 0 & 1.79 & 0.6 & 2714 \\
\hline
\end{tabular}

うな結果になったと考えられる。

4.3 周辺航空機の間隔維持を前提としない場合 2.2 .3 章の間隔維持アルゴリズムで間隔維持を行う場合では間隔 制御対象の目標経路情報や周辺の航空機の位置情報から, 間隔維持対象機がどのような操作を行うかを予測して間隔 維持方法を決定している. しかし実際の交通流では, 監視, 誘導，制御をそれぞれ自動で行う航空機やパイロットが手 動で行う航空機が混在することが想定される。また同様の 間隔維持アルゴリズムの航空機でも, パイロットの操縦ミ スなどによりその誘導に従えない可能性もある。本章では 2.2 .3 章の間隔維持アルゴリズムではなく, 自分の周辺の航 空機を監視し相手の動きに関倸なく旋回の方向を決定する 制御方法で間隔維持を行う。下の(1)(2)に各航空機が取り得 る目標経路を示す．また $V_{i}>V_{j}, y_{i}>y_{j}$ の場合の各航空 


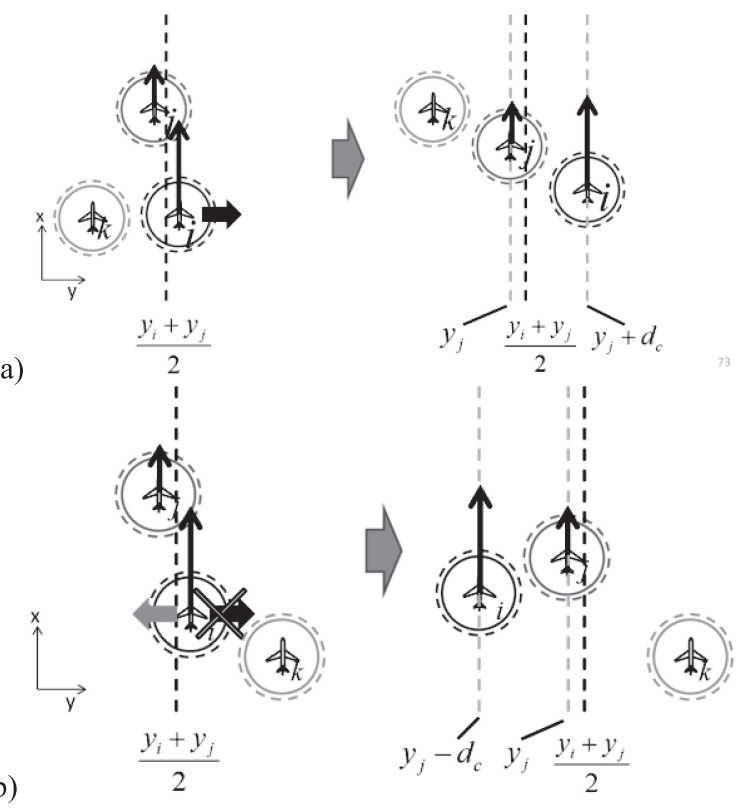

第 10 図 間隔維持の目標経路（周辺機の間隔維持を前提としない場合）
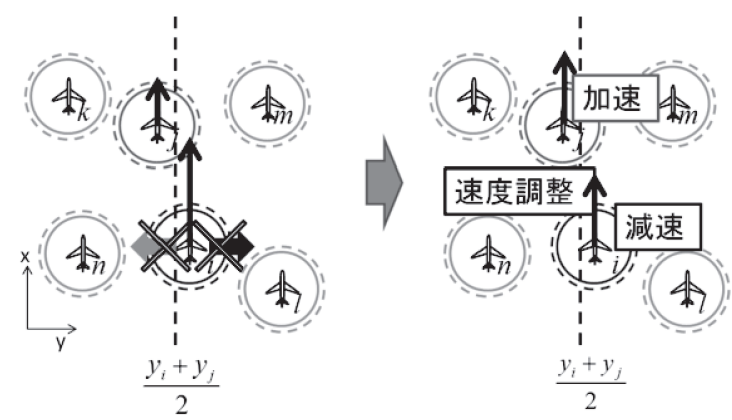

第 11 図 速度調整（周辺航空機の間隔維持を前提としない場合）

機の間隔維持の様子を第 10 図 (a), (b) に示す.

(1) 自機 $i$ が旋回順方向に安全に旋回できる場合, 旋回順 方向の $y_{j}+d_{c} \cdot \operatorname{dire}\left(V_{o i}-V_{o j}\right)$ へ経路変更を行う（第 10 図 (a)).

(2) 自機 $i$ が旋回逆方向に安全に旋回できる場合, 旋回逆 方向の $y_{j}-d_{c} \cdot \operatorname{dire}\left(V_{o i}-V_{o j}\right)$ 一経路変更を行う（第 10 図 (b)).

2.2 .3 章と同様に各航空機は(1), (2)の順に目標経路に安全に 移動できるかを周辺の航空機の情報から (14) 式から (21) 式を用いて評価を行い，すべての航空機に対して基準間隔 を維持して目標経路へ移動することができる場合，その経 路に進路を変更する．また(1)(2)で与えられる目標経路が 2.1 章で定めた解析経路の横幅の外に存在する場合はその経路 に旋回できないと判断する。(1)(2)どちらの目標経路にも 安全に経路変更できない場合は第 11 図に示すように間隔 維持対象機と速度調整を行う。速度調整中に(1)(2)のいずれ かの経路に経路変更できると判断できた場合，その経路へ 移動した後，速度調整を解除し自機の最適速度で飛行する。 このアルゴリズムの評価結果を $(\mathrm{d})$ として交通流の振る舞 いの一例と解析結果を第 12 図と第 4 表に示す。第 4 表よ
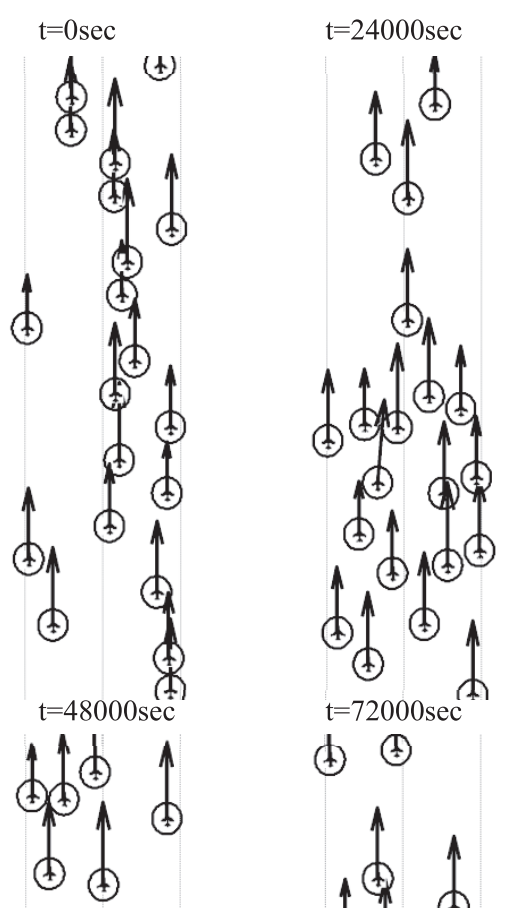

(4) ()

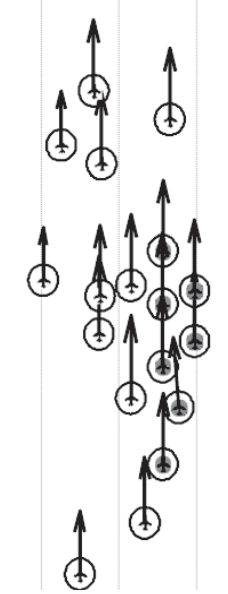

第 12 図 交通流の振る舞い（周辺航空機の間隔維持を前提としない 場合）

第 4 表 交通流評価結果（周辺航空機の間隔維持を前提としない場合）

\begin{tabular}{ccccc} 
& $\begin{array}{c}\text { コンフリクト } \\
\text { 回数 } \\
{[1 / \mathrm{hour} / \text { 機 }]}\end{array}$ & $\begin{array}{c}\text { 方位角変更 } \\
\text { 回数 } \\
{[1 / \mathrm{hour} / \text { 機 }]}\end{array}$ & $\begin{array}{c}\text { 速度調整 } \\
\text { 回数 } \\
{[1 / \text { hour } / \text { 機 }]}\end{array}$ & $\begin{array}{c}\text { 最適速度 } \\
\text { ずれ } \\
{[\mathrm{m} / \mathrm{hour} / \text { 機 }]}\end{array}$ \\
\hline (d) & 0 & 2.19 & 0.90 & 2850 \\
\hline
\end{tabular}

り 50 回通りの初期值の評価の結果, コンフリクトを発生し ない安全な交通流を形成できることが明らかとなった。し かし前章の (b) の評価結果と (d) の評価結果を比べるとパ イロットの操作回数が増加していることや, 最適速度ずれ が約 $59 \%$ 増加していることが読み取れる。また第 8 図と第 12 図を比べると第 12 図では速度に応じた経路が生成され ず速度差の大きな航空機が間隔維持を行っている. 以上の 結果より周辺航空機の間隔維持アルゴリズムの情報がない 場合，交通効率の面で悪影響を与えることが明らかとなっ た．周辺航空機の間隔維持を前提としない場合， 2.2 .3 章の 間隔維持アルゴリズムの(3)や(6)のように間隔制御対象機の 経路変更を予測した間隔維持手順をとることができないた め, 常に旋回による経路変更揖よび速度調整が必要となり, 


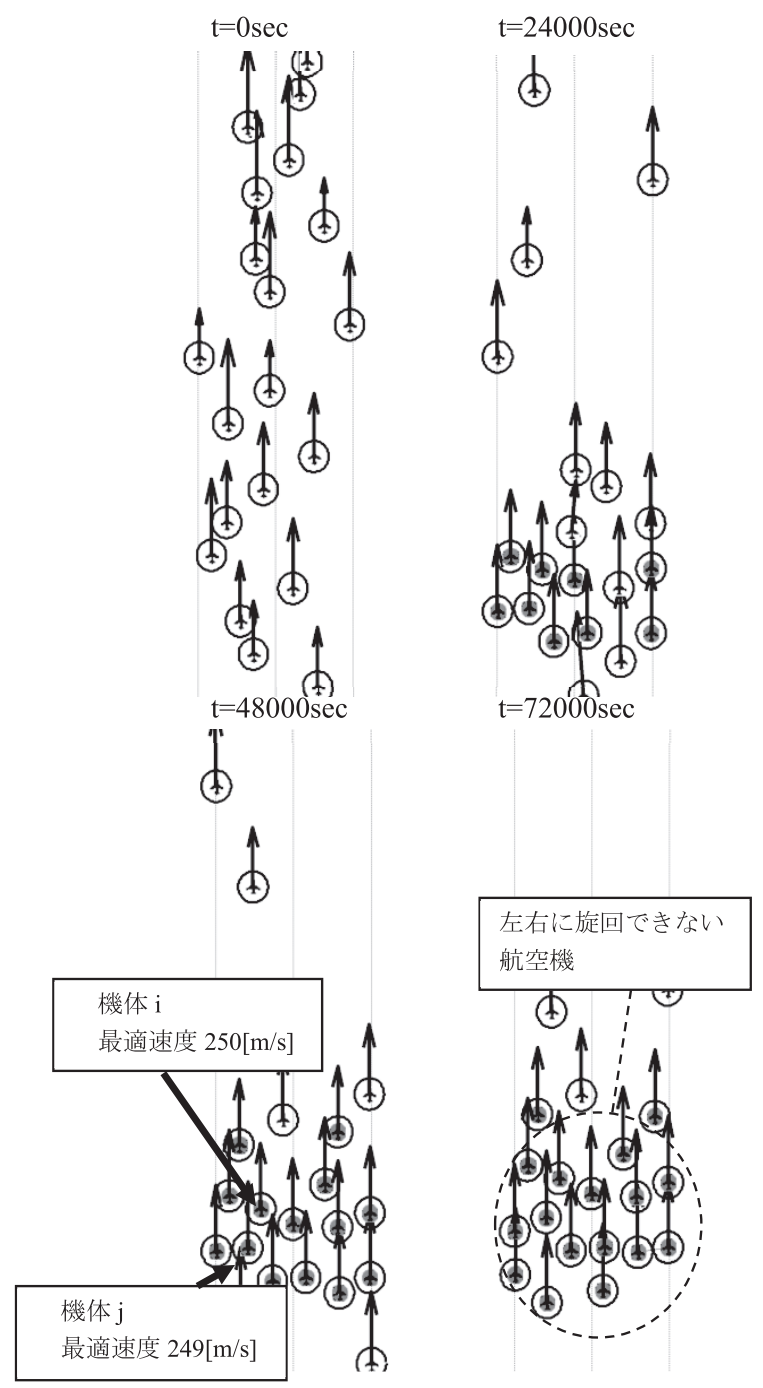

第13図 デッドロック（最適速度情報を使用しない場合）

パイロットの操作回数や速度ずれの值が大きくなったと考 えられる。

4.4 デッドロックの発生 上記の結果より周辺航空機の 最適速度の情報を使用しない場合, もしくは周辺航空機の 制御方法が分からない場合, 間隔維持対象機のすべての情 報を利用する場合と比べ最適速度ずれが増大することが明 らかとなった。第 13 図，第 14 図に 4.2，4.3 章のアルゴリ ズムで間隔維持を行う場合の交通流の一例を示す，2つの 図より速度調整を行う複数の航空機が密集し, 時間が経過 しても速度調整の状態から抜け出せない状態になっている。 本研究ではこの状態をデッドロックとする，最適速度情報 を使用しない場合交通流の一例である第 13 図の航空機 $i, j$ に着目すると, 最適速度が早い航空機が前方, 遅い航空機 が後方に位置しているにもかかわらず，この 2 機がお互い を間隔維持対象として速度調整を行っている。この状態は 速度調整により最適速度で飛行していない航空機が別の航 空機と接近する際に相手の最適速度が確認できないために 生じる。このように速度調整の状態が解消されにくく, 複 数の航空機で速度調整する頻度が増加する。そして速度調
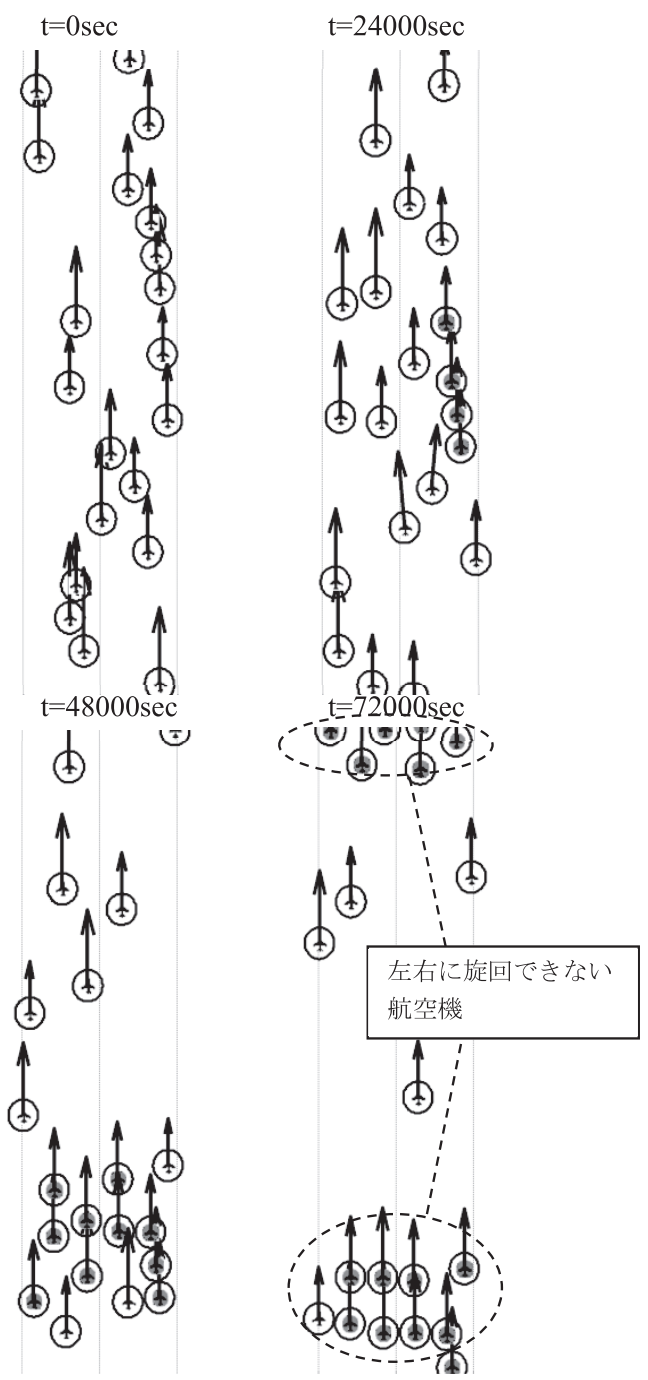

第 14 図 デッドロック（周辺航空機の間隔維持を前提としない場合）

整を行っている航空機すべてが旋回できない場合，速度調 整の状態が時間経過で解消されずデッドロックとなること が明らかとなった。

また 4.3 章の他機の間隔維持方法が自機の間隔維持方法 と同一であることを前提としない場合では，上述したよう に 3 章に比べ各航空機の間隔維持回数および速度調整を行 う時間が増加する。 その結果, 速度調整を行う航空機が密 集する確率が増加し, 航空機の初期值によってはデッドロッ クを発生する場合があることが明らかとなった。またデッ ドロックの発生頻度は, 解析経路の横幅が小さくなるに従っ て増加すると考えられる。今回の計算条件では航空機が移 動できる横幅を最適速度から $\pm 2.5 d_{c}$ までの範囲としてい るため横方向に最大 6 機の航空機が並ぶことができる。今 後の課題としてこの横幅を小さくした場合にデッドロック の発生頻度がどのように増加していくかを考察する必要が ある。

\section{5. 結言}

本研究では監視, 誘導, 制御のうち制御をパイロットの 
マニュアルの操作で行うことを想定した間隔維持アルゴリ ズムを提案した. ADS-B から得られる周辺の航空機の位 置, 速度, 方位角の情報の他に最適速度情報を使用した自 律間隔維持方式に従うことにより，パイロットは 1 時間当 たり平均 3 回未満の速度, 方位角の変更で周辺航空機と所 要の間隔を維持して航行できることが明らかとなった。ま た周辺航空機の最適速度情報が得られない場合, および間 隔維持対象機の間隔維持アルゴリズムが分からない場合に は安全に航行することはできるが，パイロットの操作量や 最適速度からのずれが増加するなど，運航効率が低下する ことを明らかにした。管制官の指示を受けずに各航空機の 監視情報のみで間隔維持をする場合，位置および速度の情 報に加え周辺航空機の最適速度情報や間隔維持方式の情報, 目標経路情報などを送受信したり, 協調的な間隔維持を行 うことによりさらに効率のよい航空交通流を形成できるこ とを明らかにした。

本研究では, パイロットの手動の操縦による間隔維持を 可能にすると考えられる自律間隔維持方式を明らかにした。 現実の高密度交通流におけるこの方式の実現可能性を明ら かにするためには, 今後, 高密度交通流内部を飛行する航 空機を模擬したフライトシミュレータを用い, 実際のパイ ロットによる評価を行うなど，より実際に近い状況での検 証が不可欠である。そしてこれにより実用化までの課題を 明らかにし，最終的には実機による実証を経なければなら ない.これらが今後の重要な課題となる。

\section{参 考 文 献}

1）今若善紀：運輸多目的衛星（MTSAT）を利用した航空管制，電 子情報通信学会技術研究報告, 102, 172 (2002), pp. 51-54.

2) 国土交通省：MTSAT 導入の効果, http://www.mlit.go.jp/ koku/15_bf_000368.html

3) 福島幸子, 福田 豊, 住谷美登里：北太平洋上の東行き最適経路 の傾向について, 第 9 回電子航法研究所研究発表会, 2009 .

4) 国土交通省：航空需要予測について（資料 1)，交通政策審議会 第 9 回航空分科会資料, 2007.

5) 長岡 栄：航空交通管制（ATM）と最近の技術動向，第 116 回 日本航海学会航空宇宙研究会, 2007.

6) FAA/Eurocontrol Cooperative R\&D Committee: Principles of Operation for the Use of Airborne Separation Assurance Systems Version: 7.1, 2001, http://adsb.tc.faa.gov/RFG/poasas71.pdf

7) Japan Civil Aviation Bureau: Long-term Vision for the Future Air Traffic Systems (CARATS), 2010, http://www. mlit.go.jp/koku/koku_CARATS.html

8) Joint Planning and Development Office: Concept of Operation for the Next Generation Air Transportation System Ver. 3.2., Sep. 30, 2010, http://jpe.jpdo.gov/ee/docs/ conops/NextGen_ConOps_v3_2.pdf
9) SESAR Consortium: European Air Traffic Management Master Plan, Edition 1, 2009.

10) Bilimoria, K. D.: A Geometric Optimization Approach to Aircraft Conflict Resolution, AIAA Paper 2000-4265, AIAA Guidance, Navigation, and Control Conference, Denver, Colo., 2000.

11) Erzberger, H.: Automated Conflict Resolution for Air Traffic Control, 25th International Congress of the Aeronautical Sciences, 2006.

12) Cuevas, G., Echegoyen, I., García, J., Cásek, P., Keinrath, C., Bussink, F. and Luuk, A.: Autonomous Aircraft Advanced (A3) ConOps, iFly Project, Technical Report Deliverable D1.3, 2008.

13) Bach, R., Farrell, C. and Erzberger, H.: An Algorithm for Level-aircraft Conflict Resolution, NASA/CR-2009-214573, 2009.

14) Abbott, T. S.: Speed Control Law for Precision Terminal Area In-trail Self Spacing, NASA TM-2002-211742, 2002.

15) Ivanescu, D., Shaw, C., Zeghal, K. and Hoffman, E. Propagation of Airborne Spacing Errors in Merging Traffic Streams, Proceedings of the 7th USA/Europe Air Traffic Management R\&D Seminar, Barcelona, Spain, 2007.

16) Barmore, B. E., Abbott, T. S., Capron, W. R. and Baxley, B. T.: Simulation Results for Airborne Precision Spacing along Continuous Descent Arrivals, Proceedings of the AIAA Aviation Technology, Integration, and Operations Conference, 2008

17) Weitz, L. A.: Investigating String Stability of a Timehistory Control Law for Interval Management, Transportation Research Part C: Emerging Technologies, 33 (2013), pp. 257-271, available on line: http://dx.doi.org/10.1016/ j.trc.2011.10.002

18）中村陽一，武市 昇：機上周辺監視による一方向航空交通流の制 御, 日本航空宇宙学会論文集, 59 (2011), pp. 76-82.

19）中村陽一, 武市 昇: 飛行速度のばらつきのある一方向航空交通 流の機上周辺監視による分散制御, 日本航空宇宙学会論文集, 60 (2012), pp. 17-23.

20) Takeichi, N., Nakamura, Y. and Fukuoka, K.: Fundamental Characteristics of Decentralized Air Traffic Flow Control in High Density Corridor, 28th International Congress of the Aeronautical Sciences, 2012.

21) Takeichi, N., Nakamura, Y. and Fukuoka, K.: Decentralized Control in a High Density Air Corridor Subject to Separation Control Non-uniformity, Trans. Jpn. Soc. Aeronaut. Space Sci., 56 (2013), pp. 153-158.

22）福岡敬介, 武市 昇, 中村陽一：高密度航空交通流に打ける速 度調整によるコンフリクト回避，日本航空宇宙学会論文集， 61 (2013), pp. 119-124.

23）武市 昇, 中村陽一, 蔭山康太：フローコリドーの概念と実用化 への課題, 日本航空宇宙学会誌, 60 (2012), pp. 449-454.

24) EUROCONTROL Experimental Centre: User Manual for the Base of Aircraft Data (BADA), Revision 3.7. EEC Note 10/04, 2009.

25) Nakamura, Y., Takeichi, N. and Kageyama, K.: A SelfSeparation Algorithm Using Relative Speed for High Density Air Corridor, AIAA Paper 2013-5069, AIAA Modeling and Simulation Technologies Conference, Boston, 2013. 